\title{
Aerobic Exercise Training Effects on Omentin-1, Insulin Resistance and Lipid Profile Among Male Smokers
}

\section{Seyed Maysam Mousavi}

Bu-Ali Sina University: Bu Ali Sina University

Ali Heidarianpour ( $\square$ Heidarian317@gmail.com )

Bu-Ali Sina University: Bu Ali Sina University

Hassan Tavassoli

Bu-Ali Sina University: Bu Ali Sina University

\section{Research}

Keywords: Aerobic exercise, Insulin resistance, Lipid profile, Omentin-1, Smokers

Posted Date: December 23rd, 2020

DOI: https://doi.org/10.21203/rs.3.rs-131076/v1

License: (c) (i) This work is licensed under a Creative Commons Attribution 4.0 International License.

Read Full License 


\section{Abstract}

Background: Omentin-1 is a recently discovered circulating adipokine that plays a crucial role in modulating insulin resistance and diabetes. We investigated the effect of eight weeks of aerobic exercise training on serum omentin-1, insulin resistance and lipid profile in the smokers and non-smokers with normal weight.

Methods: Nineteen male healthy and twenty male smokers were randomly assigned into healthy control group (C), healthy exercise group (E), control smoker group (CS) and exercise smoker group (ES). Exercise groups participated in an eight-week aerobic exercise training program (three times a week, 20-35 min per session at $55 \%-70 \%$ of maximum heart rate). Serum omentin- 1 and insulin values were determined by ELISA and Homeostatic Model Assessment for Insulin Resistance (HOMA-IR), glucose and lipid profile was measured before and after the intervention. Paired samples t-test, one-way analysis of variance (Oneway ANOVA) and post-hoc Tukey test were applied to analyze the data $(p<0.05)$.

Results: Aerobic exercise improved both serum omentin-1 and high lipoprotein cholesterol (HDL-C) in the exercise groups $(p<0.05)$. Also, Exercise training reduced insulin, blood sugar, HOMA-IR, total cholesterol (TC) and low-density lipoprotein cholesterol (LDL-C) levels $(p<0.05)$. Omentin-1 was significantly correlated with insulin $(r=-0.40, P=0.01)$, HOMA-IR $(r=-0.38, P=0.04), T G(r=-0.40, P=0.01), T C(r=-0.49$, $P=0.02)$, LDL-C $(r=-0.70, P=0.02)$ and HDL-C $(r=0.55, P=0.03)$.

Conclusion: The findings suggest that aerobic exercise-induced changes in omentin- 1 in exercise trained smokers may be associated with the beneficial effects of exercise on reduced insulin resistance and lipid profile.

\section{Introduction}

Smoking is linked to higher risk of developing many respiratory infection diseases and cardiovascular diseases in the smoker population [1]. The results of a study showed that smokers (aged under 65 years) with a normal weight and current smokers, had an increased risk of death compared to the obese and non-smokers [2]. The evidence confirmed that cigarette smoking was associated with altered normal status of the lipid profile. So, there was a significant increase in the levels of total cholesterol (TC), triglyceride (TG), low density lipoprotein (LDL-C), very low density lipoprotein (VLDL) and reduced level of high lipoprotein cholesterol (HDL-C) among smokers [3]. In fact, smoking leads to accumulation of central fat and, thereby, insulin resistance in these individuals. Consequently, smoking increases the risk of metabolic syndrome and incidence of diabetes, and these changes increase the risk of developing cardiovascular diseases [4].

Meanwhile, the adipose tissue, as an active endocrine organ, produces bioactive peptides and proteins called "adipokines". Some of these adipokines lead to the prevalence of insulin resistance and cardiovascular complications linked to obesity [5]. Omentin-1, a novel adipokine, is the main isoform of omentins in circulating plasma levels of human, which is mainly secreted from the visceral adipose 
tissue [6-7]. Recent evidence points to the possible role of omentin-1 in the pathophysiology of obesity and insulin resistance [8]. The omentin-1 circulating levels are inversely related to insulin resistance and are decreased in obesity as well as type 2diabetes [9]. Ansari et al. [10] newly reported a decrease in omentin-1 serum level among smokers as a metabolic risk factor and as a major prognostic agent of lung cancer in these individuals. Low omentin-1 levels in response to cigarette smoking can cause an immunomodulatory effect on the immune system that appears to raise the risk of exposure to infections in smokers [11]. However, the exact mechanism underlying the reduced omentin level observed in smokers is little understood.

Exercise training is an important non-pharmacological strategy to improve insulin sensitivity via several metabolic/physiological changes [9]. Since, regular exercise training diminishes the risk factors for metabolic diseases such as obesity, type 2diabetes, and cardiovascular diseases [12], it may modify circulating omentin-1 level. In this regard, Saremi et al. [6] have reported an incremental change in omentin-1 concentration following 12 weeks of aerobic training in obese participants, but Faramarzi et al. [13] observed no statistically significant change in its level after 12 weeks of exercise program in overweight women. However, until now, the effect of exercise training interventions on omentin-1 level has not been explored in smokers. Therefore, the changes of omentin- 1 and the possible association between its serum level and metabolic parameters following exercise training can provide new insight into the mechanisms underlying the benefits of exercise training in smokers. To the authors' knowledge, this is the first study to determine the effect of an exercise intervention program on circulating omentin-1 level and its associations with some metabolic parameters in apparently healthy smokers with normal weight.

\section{Materials And Methods}

\section{Participants}

This was a semi-experimental study with pre- and post-training and control group design. For this purpose, nineteen healthy and twenty young smokers (all male) were randomly assigned into healthy control; C group ( $n=9$; age $27.6 \pm 2.5$ years, BMI $\left.22.61 \pm 1.94 \mathrm{~kg} \cdot \mathrm{m}^{-2}\right)$, healthy exercise; E group $(n=10$; age $28 \pm 2.73$ years, BMI $\left.22.77 \pm 1.67 \mathrm{~kg} \cdot \mathrm{m}^{-2}\right)$, control smoker; $\mathrm{CS}$ group $(\mathrm{n}=9$; age $29.3 \pm 2.51$ years, $\mathrm{BMI}$ $\left.23.59 \pm 2.23 \mathrm{~kg} \cdot \mathrm{m}^{-2}\right)$ and exercise smoker; ES group ( $\mathrm{n}=11$; age $30.5 \pm 1.7$ years, BMI $22.72 \pm 1.69 \mathrm{~kg} \cdot \mathrm{m}^{-}$ 2). The smokers consumed approximately 11-16 cigars per day at least for five years. The subjects were non-athletes, meaning that they had not participated in any regular exercise during the last six months. We excluded subjects who had metabolic or chronic inflammatory disorders, cardiovascular diseases or any other major illness that could affect the results. The exercise groups participated in an eight-week aerobic training program, while the control groups maintained their normal lifestyle. The physical training activity of the participants was determined during one of the experimental sessions. All experimental procedures were approved by the ethics committee of Bu-Ali Sina University (Hamedan, Iran). All the participants filled in written informed consent forms after being briefed on all the necessary researchrelated details. 


\section{Aerobic exercise training program}

The aerobic training program was performed 20-35 min a day, 3 days a week for eight consecutive weeks. All exercises training was supervised by an expert exercise physiologist. Each session was executed in three continuous stages as follows: warm-up by exercises including marching, walking briskly, and jogging for 10 min, main activity (aerobic training program) and cool-down by walking, slow jogging and typical post-running stretches for $10 \mathrm{~min}$.

Exercise sessions lasted 20 minutes and the initial intensity of training was set at $55-65 \%$ of an individual's maximal heart rate (MHR) for the first four weeks and was progressively increased to $70 \%$ of MHR for $35 \mathrm{~min}$ at the 8th week of the protocol [14]. We used an age-based prediction Eq. (220 - age) for calculating the predicted MHR. Heart rate was checked continuously during all exercise sessions using a Beurer's PM 100 beltless Heart rate monitor (made in Germany) after calibration according to the manufacturer guidelines.

\section{Experimental Measurements}

All baseline measurements were performed prior to the beginning of the protocol, and post testing evaluations were made $48 \mathrm{~h}$ after the last session of the training program. Omentin-1 serum level was analyzed by a commercial ELISA kit (Eastbiopharm, Hangzhou, China). The intra-assay and inter-assay coefficients of variation were less than $12 \%$, and sensitivity of the assay was $1.03 \mathrm{ng} / \mathrm{mL}$. The serum values of $\mathrm{HDL}-\mathrm{C}, \mathrm{TG}$, and TC concentrations were measured by an enzymatic colorimetric method using biochemical Auto-analyzer Prestige 24i (Made in Japan). LDL-C level was estimated using the Friedewald formula when serum TG was $<400 \mathrm{mg} / \mathrm{dL}$. The glucose level was determined using the glucose oxidase method kit (Pars Azmoon, Tehran, Iran). Insulin concentration was assayed using the chemiluminescence method (LIAISON®, Germany). The Homeostasis model assessment for insulin resistance (HOMA-IR) was used to calculate insulin resistance, and it was estimated from fasting glucose and insulin, according the following equation: [Fasting glucose $(\mathrm{mg} / \mathrm{dl}) \times$ fasting insulin (U/l)/405] [15].

\section{Statistical analysis}

The results are expressed as the mean \pm standard deviation. All the statistical analyses were conducted on the SPSS (version 22) software at the level of significance of 0.05 . Assumption of normal distribution of the data and homogeneity of variances were verified by the Shapiro-Wilk test and Levene test. Paired sample t-test was performed to examine within group differences before and after the eight-week exercise intervention in each group. One-way analysis of variance (ANOVA) followed by Tukey's post hoc test was applied to find the differences among the groups. The correlations between the variables were estimated by Pearson's correlation test.

\section{Results}

Anthropometrical and metabolic characteristics (mean \pm SD) of the participants at baseline and after the eight-week exercise intervention are presented in Table 1. After eight weeks of aerobic training, the ES 
group experienced weight loss, which was accompanied by significant reductions in body mass index (BMI), glucose, insulin resistance index, TG, TC, and LDL-C levels $(P<0.05)$. In addition, omentin-1 and HDL-C serum concentrations increased significantly in the exercise groups $(P<0.05)$ (see Table 1 and Fig. 1). 
Table 1

Participant characteristics before and after 8 weeks of aerobic training (mean \pm SD).

\begin{tabular}{|c|c|c|c|c|c|c|c|c|}
\hline & \multicolumn{2}{|c|}{ C group $(n=9)$} & \multicolumn{2}{|c|}{ E group $(n=10)$} & \multicolumn{2}{|c|}{ CS group $(n=9)$} & \multicolumn{2}{|c|}{ ES group $(n=11)$} \\
\hline & Before & After & Before & After & Before & After & Before & After \\
\hline Anthropometry & $\begin{array}{l}27.6 \pm \\
2.5\end{array}$ & - & $\begin{array}{l}28 \pm \\
2.73\end{array}$ & - & $\begin{array}{l}29.3 \pm \\
2.51\end{array}$ & - & $\begin{array}{l}30.5 \pm \\
1.7\end{array}$ & - \\
\hline $\begin{array}{l}\text { age (years) } \\
\text { height }(\mathrm{cm})\end{array}$ & $\begin{array}{l}174.83 \\
\pm 4.75\end{array}$ & - & $\begin{array}{l}171.7 \\
\pm 6.61\end{array}$ & - & $\begin{array}{l}173 \pm \\
4.15\end{array}$ & - & $\begin{array}{l}178.16 \\
\pm 8.58\end{array}$ & \\
\hline Weight (kg) & $\begin{array}{l}69.3 \pm \\
8.7\end{array}$ & $\begin{array}{l}69 \pm \\
8.5\end{array}$ & $\begin{array}{l}66.8 \pm \\
9.7\end{array}$ & $\begin{array}{l}65.2 \pm \\
9.3^{\#}\end{array}$ & $\begin{array}{l}70.8 \pm \\
4.8\end{array}$ & $\begin{array}{l}70.6 \pm \\
3.5\end{array}$ & $\begin{array}{l}72.3 \pm \\
9.6\end{array}$ & $\begin{array}{l}69 \pm \\
9.2^{*}\end{array}$ \\
\hline BMI $\left(\mathrm{kg} . \mathrm{m}^{-2}\right)$ & $\begin{array}{l}22.61 \\
\pm 1.94\end{array}$ & $\begin{array}{l}22.51 \\
\pm 2\end{array}$ & $\begin{array}{l}22.77 \\
\pm 1.76\end{array}$ & $\begin{array}{l}22.25 \\
\pm 1.64\end{array}$ & $\begin{array}{l}23.59 \\
\pm 2.23\end{array}$ & $\begin{array}{l}23.54 \\
\pm 1.95\end{array}$ & $\begin{array}{l}22.72 \\
\pm 1.69\end{array}$ & $\begin{array}{l}21.67 \pm \\
1.69 * \#\end{array}$ \\
\hline \multicolumn{9}{|l|}{$\begin{array}{l}\text { Insulin } \\
\text { resistance }\end{array}$} \\
\hline $\begin{array}{l}\text { Glucose (mg. } \\
\left.\mathrm{dl}^{-2}\right)\end{array}$ & $\begin{array}{l}86.06 \\
\pm 3.47\end{array}$ & $\begin{array}{l}86.43 \\
\pm 3.49\end{array}$ & $\begin{array}{l}85.95 \\
\pm 5.31\end{array}$ & $\begin{array}{l}76.41 \\
\pm \\
4.72^{\star \#}\end{array}$ & $\begin{array}{l}86.11 \\
\pm 5.47\end{array}$ & $\begin{array}{l}86.16 \\
\pm 6.49\end{array}$ & $\begin{array}{l}86 \pm \\
1.41\end{array}$ & $\begin{array}{l}75.16 \pm \\
5.7^{* \#}\end{array}$ \\
\hline $\begin{array}{l}\text { Insulin }(\mu \mathrm{U} . \\
\left.\mathrm{ml}^{-2}\right)\end{array}$ & $\begin{array}{l}5.37 \pm \\
0.66\end{array}$ & $\begin{array}{l}5.39 \pm \\
1.19\end{array}$ & $\begin{array}{l}5.39 \pm \\
2.79\end{array}$ & $\begin{array}{l}2.99 \pm \\
2.1^{*}\end{array}$ & $\begin{array}{l}5.36 \pm \\
0.29\end{array}$ & $\begin{array}{l}5.37 \pm \\
0.99\end{array}$ & $\begin{array}{l}5.37 \pm \\
1.55\end{array}$ & $\begin{array}{l}3 \pm \\
0.75^{*}\end{array}$ \\
\hline HOMA-IR & $\begin{array}{l}1.1 \pm \\
0.12\end{array}$ & $\begin{array}{l}1.13 \pm \\
0.12\end{array}$ & $\begin{array}{l}1.21 \pm \\
0.48\end{array}$ & $\begin{array}{l}0.57 \pm \\
0.31^{\star \#}\end{array}$ & $\begin{array}{l}1.16 \pm \\
0.2\end{array}$ & $\begin{array}{l}1.41 \pm \\
0.34\end{array}$ & $\begin{array}{l}1.17 \pm \\
0.23\end{array}$ & $\begin{array}{l}0.67 \pm \\
0.26^{\star \#}\end{array}$ \\
\hline \multicolumn{9}{|l|}{ Lipid profile } \\
\hline TG (mg.dl-2) & $\begin{array}{l}116.8 \\
\pm 6.69\end{array}$ & $\begin{array}{l}116.69 \\
\pm 5.74\end{array}$ & $\begin{array}{l}116.83 \\
\pm 10.18\end{array}$ & $\begin{array}{l}99.33 \\
\pm 6.62^{*}\end{array}$ & $\begin{array}{l}131.16 \\
\pm 18.14\end{array}$ & $\begin{array}{l}131.5 \\
\pm 12.77\end{array}$ & $\begin{array}{l}131.66 \\
\pm 24.88\end{array}$ & $\begin{array}{l}103 \pm \\
27.8^{\star \#}\end{array}$ \\
\hline TC (mg.dl-2) & $\begin{array}{l}149.4 \\
\pm 7.5\end{array}$ & $\begin{array}{l}149.16 \\
\pm 3.73\end{array}$ & $\begin{array}{l}149.6 \\
\pm 7.12\end{array}$ & $\begin{array}{l}137 \pm \\
9.03^{*}\end{array}$ & $\begin{array}{l}158.4 \\
\pm 10.28\end{array}$ & $\begin{array}{l}158.16 \\
\pm 7.7\end{array}$ & $\begin{array}{l}158 \pm \\
19.18\end{array}$ & $\begin{array}{l}142.2 \pm \\
24.18^{\star \#}\end{array}$ \\
\hline $\begin{array}{l}\mathrm{HDL}-\mathrm{C}\left(\mathrm{mg} \cdot \mathrm{dl}^{-}\right. \\
\left.{ }^{2}\right)\end{array}$ & $\begin{array}{l}37.96 \\
\pm 10.5\end{array}$ & $\begin{array}{l}38 \pm \\
8.04\end{array}$ & $\begin{array}{l}38.25 \\
\pm 2.21\end{array}$ & $\begin{array}{l}42 \pm \\
2.7^{\star}\end{array}$ & $\begin{array}{l}37.8 \pm \\
5.48\end{array}$ & $\begin{array}{l}38 \pm \\
7.02\end{array}$ & $\begin{array}{l}38 \pm \\
4.96\end{array}$ & $\begin{array}{l}42.5 \pm \\
5.44^{*}\end{array}$ \\
\hline $\begin{array}{l}\text { LDL-C (mg.dl- } \\
\left.{ }^{2}\right)\end{array}$ & $\begin{array}{l}80.3 \pm \\
9.57\end{array}$ & $\begin{array}{l}80.27 \\
\pm 6.32\end{array}$ & $\begin{array}{l}80.48 \\
\pm 14.8\end{array}$ & $\begin{array}{l}70.83 \\
\pm \\
8.72^{\star \#}\end{array}$ & $\begin{array}{l}83.36 \\
\pm 10.6\end{array}$ & $\begin{array}{l}84.5 \pm \\
7.67\end{array}$ & $\begin{array}{l}81.24 \\
\pm 13.52\end{array}$ & $\begin{array}{l}67.36 \pm \\
15.54^{\star \# \#}\end{array}$ \\
\hline
\end{tabular}

After the 8 weeks of aerobic exercise training, inverse relationships were identified between omentin-1 and glucose $(r=-0.37, P=0.05)$, insulin $(r=-0.40, P=0.01)$, HOMA-IR $(r=-0.38, P=0.04), T G(r=-0.40, P=0.01)$, 
$T C(r=-0.49, P=0.02)$, and LDL-C $(r=-0.70, P=0.02)$. Also, a positive correlation was found between omentin-1 and HDL-C $(r=0.55, P=0.03)$ (see Table 2$)$.

Table 2

Pearson correlations of omentin-1 with anthropometric and metabolic variables after exercise in smoker exercise group

\begin{tabular}{|lll|}
\hline Variables & $\mathbf{p}$ & Correlation \\
\hline Weight $(\mathrm{kg})$ & 0.76 & -0.38 \\
\hline BMI $\left(\mathrm{kg} \cdot \mathrm{m}^{-2}\right)$ & 0.71 & -0.48 \\
\hline Glucose $\left(\mathrm{mg} \cdot \mathrm{dl}^{-2}\right)$ & 0.05 & -0.37 \\
\hline Insulin $\left(\mu \mathrm{U} \cdot \mathrm{ml}^{-2}\right)$ & 0.01 & -0.40 \\
\hline HOMA-IR & 0.04 & -0.38 \\
\hline TG $\left(\mathrm{mg} \cdot \mathrm{dl}^{-2}\right)$ & 0.01 & -0.40 \\
\hline TC $\left(\mathrm{mg} \cdot \mathrm{dl}^{-2}\right)$ & 0.02 & -0.49 \\
\hline LDL-C $\left(\mathrm{mg} \cdot \mathrm{dl}^{-2}\right)$ & 0.02 & -0.70 \\
\hline HDL-C $\left(\mathrm{mg} \cdot \mathrm{dl}^{-2}\right)$ & 0.03 & 0.55 \\
\hline $\begin{array}{l}\text { Note: } \mathrm{HOMA}^{-} \text {-IR = homeostasis model assessment for insulin resistance; LDL-C = low-density } \\
\text { lipoprotein cholesterol; HDL-C = high-density lipoprotein cholesterol }\end{array}$ & \\
\hline
\end{tabular}

\section{Discussion}

In the present study, we investigated the effects of eight weeks of aerobic exercise training in male smokers with normal weight. Body variables (i.e. body weight and $\mathrm{BMI}$ ), insulin resistance (i.e. fasting glucose, insulin, and HOMA-IR), and blood lipid profile (i.e. TG, TC, LDL-C) decreased in the ES group compared to the CS group after the eight-week exercise intervention. Our results are in line with those of previous observations and reinforce the beneficial effect of exercise training on these important metabolic factors in confronting many diseases such as metabolic syndrome, type 2 diabetes, and cardiovascular diseases $[6,16-17]$.

Many studies have found lower levels of omentin-1 in obesity, impaired glucose tolerance and type 2diabetes [18-20]. Also, lower levels of omentin in response to smoking may contribute to increased susceptibility to infections in smokers [11]. In order to investigate the changes of omentin-1 in smokers, we explored the effect of eight weeks of aerobic exercise training on circulating omentin-1 in smokers and examined the omentin-1 response in relation to insulin resistance. The findings showed that the eightweek of aerobic exercise training at $55-70 \%$ of MHR led to a marked increase in omentin- 1 concentration in the $\mathrm{E}$ and $\mathrm{ES}$ groups. Unfortunately, to the best of our knowledge, no study to date has examined the 
effect of exercise on circulating omentin-1 level in smokers. Nevertheless, some studies have been carried out on the effect of exercise training on omentin-1 [21]. Our result was consistent with that of Wilms et al. [22], Ouerghi et al. [23], and Saremi et al. [6], who also found an increase in omentin level following exercise, and is inconsistent with the results of Faramarzi et al. [13]. It seems that an intensity threshold is essential to improve plasma omentin-1 level, which can be the cause of the inconsistency with the findings of some studies [24].

We found that an increase in concentrations of serum omentin-1 was along with reduced blood glucose, fasting insulin level, HOMA-IR and some lipid profiles after the eight-week exercise training program [21]. In the present study, eight weeks of aerobic exercise training effectively lowered insulin resistance in both trained smoker and non-smoker groups, which is in line with the findings of previous studies [17].

The role of omentin-1 in type 2 diabetes is also unclear. Omentin induces anti-inflammatory, antiatherogenic and anti-diabetic effects $[19,25]$. But, recently two studies have found a relationship between omentin- 1 and increased risk of type 2 diabetes and cardiovascular diseases [26, 27]. In the study by Ouerghi et al. [28], omentin-1 was inversely correlated with cardio-metabolic risk factors, while the relationship disappeared after adjusting on potential confounders. They reported that omentin-1 was inversely correlated with insulin resistance and this adipokine could improve glucose metabolism and insulin sensitivity [28].

In line with our findings, previous studies have reported that omintin-1 has a negative correlation with fasting insulin, and HOMA-IR $[18,29]$. Therefore, the mechanism for increased omentin is directly related to weight loss and a decrease in BMI after exercise training. In this regard, Moreno-Navarrete et al. [30] reported that the concentration of circulating omentin-1 rises after weight reduction, which is consistent with our observation.

The results of the present study showed that the levels of insulin, glucose and insulin resistance were reduced in the two training groups. Not much research has been done on the mechanism of omentin-1 and its association with glucose and insulin levels, but the few studies in this regard have confirmed the role of omentin-1 in transmitting insulin signaling via kinase B protein/Akt activation and increasing the insulin-stimulated glucose uptake into the adipose tissue [18]. Also, omentin-1 can improve glucose metabolism and insulin sensitivity by increasing glucose transport into the muscles following exercise training. According to the results of Castro et al. [31], there is an association between skeletal muscle and adipose tissue in relation to omentin-1. In fact, exercise training causes an increase in omentin gene expression in adipocytes tissue and improves insulin sensitivity [32]. Nonetheless, there is an inconsistency in terms of the relationship between omentin level and insulin resistance between the results of the present study and those of Hossein-Nezhad et al. [8], which might be due to various subject populations or other undefined components that may influence omentin-1 level.

In the current study, we discovered inverse correlations between serum omentin-1 level and TG, LDL-C, and TC. A direct correlation was also identified between omentin-1 and HDL-C levels. Contrary to our results, Hossein-Nezhad et al. [8] and Elsaid et al. [33] did not observe any significant relationship 
between serum omentin-1 and lipid levels. Moreno-Navarrete et al. [30] reported that omentin level was correlated with some lipid metabolic parameters such as TC, LDL-C, and TG. Abd-Elbaky et al. [34] also found an inverse relationship between omentin-1 and TC levels in adults, which is concurrent with our findings. It is proposed that the differences in body fat distribution in the subjects studied may impact on the production or secretion of adipokines and the results of investigations [35]. Omentin seems to play an important role in lipid metabolism regulation and so against diabetic dyslipidemia as a compensatory mechanism [30] since it has been shown that omentin-1 promotes 5-AMP-activated protein kinase phosphorylation, which acts as an inhibitor of endogenous cholesterol synthesis [21].

Moreover, in agreement with earlier findings [7, 19], we found out serum level of omentin-1 was positively associated with HDL-C level. It was suggested that omentin has anti-atherogenic behavior, thus it can affect HDL-C level through modulating insulin action [25,36]. The potential mechanism involved in the increased HDL-C level following aerobic exercise training in the smokers may be linked to modifications in the activities of some enzymes such as lipoprotein lipase and lecithin-cholesterol acyltransferase and hepatic triglyceride lipase [37].

\section{Limitations}

Lack of diet control and the small number of participants (sample size) can be considered as the major limitations of the present study. Further investigation based on exercise intervention and implementation of de-training along with diet control in a larger population is suggested to clarify the underlying mechanisms of omentin-1 in smokers.

\section{Conclusion}

The results of the present study suggest that eight weeks of aerobic exercise training enhances glucose/lipid metabolism and, thereby, can reduce complications of smoking through omentin-1 among smokers with normal weight. Omentin-1 had a significant relationship with BMI, insulin resistance and lipid profile. However, the physiological and regulatory role of omentin-1 in energy metabolism following different exercise training protocols (and also detraining period) in smokers is not very well understood. Further experimental studies need to be conducted in this regard.

\section{Abbreviations}

BMI: Body mass index; HDL-C: High lipoprotein cholesterol; HOMA-IR: Homeostasis model assessment of insulin resistance; LDL-C: Low-density lipoprotein cholesterol; MHR: Maximal heart rate; TC: Total cholesterol; TG: Triglyceride; VLDL: Very low density lipoprotein

\section{Declarations}

Acknowledgement 
We would like to thank participants in this study, and the Research Deputy of the University, for his kind help and cooperation.

\section{Authors Contributions}

Dr. Heidarianpour designed the study. Mr. Mousavi performed the exercise protocol, collected the blood samples, and analyzed the data. Dr. Heidarianpour and Dr. Tavassoli contributed to write the discussion and the manuscript. All authors have approved the final version of the manuscript.

\section{Funding}

This research received no specific grants from any funding agency in the public, commercial, or not-forprofit sectors.

\section{Availability of data and materials}

All data generated or analysed during this study are included in this published article.

\section{Ethical approval}

The experimental protocol was in accordance with institutional guidelines and approved by the Ethics Committee of the University. All participants signed voluntary consent forms prior to research commencement.

\section{Competing interests}

"The authors declare that they have no competing interests".

\section{Author details}

${ }^{1}$ Department of Exercise Physiology, Faculty of Physical Education and Sport Science, Bu-Ali Sina University, Hamedan, Iran

\section{References}

1. Malenica M, Prnjavorac B, Bego T, Dujic T, Semiz S, Skrbo S, et al. Effect of cigarette smoking on haematological parameters in healthy population. Med Arch. 2017; 71(2): 132-136. https://doi.org/10.5455/medarh.2017.71.132-136 PMID: 28790546.

2. Freedman DM, Sigurdson AJ, Rajaraman P, Doody MM, Linet MS, Ron E. The mortality risk of smoking and obesity combined. Am J Prev Med. 2006; 31(5):355 - 62. https://doi.org/10.1016/j.amepre.2006.07.022 PMID: 17046405.

3. Hallit S, Zoghbi M, Hallit R, Youssef L, Costantine R, Kheir N, et al. Effect of exclusive cigarette smoking and in combination with waterpipe smoking on lipoproteins. J Epidemiol Glob Health. 2017; 7(4):269-275. https://doi.org/10.1016/j.jegh.2017.08.006 PMID: 29110868. 
4. Chiolero A, Faeh D, Paccaud F, Cornuz J. Consequences of smoking for body weight, body fat distribution, and insulin resistance. Am J Clin Nutr. 2008; 87(4):801-9. https://doi.org/10.1093/ajcn/87.4.801 PMID: 18400700.

5. Rabe K, Lehrke M, Parhofer KG, BroedI UC. Adipokines and insulin resistance. Mol Med. 2008;14(1112):741-51. https://doi.org/10.2119/2008-00058.Rabe PMID: 19009016.

6. Saremi A, Asghari M, Ghorbani A. Effects of aerobic training on serum omentin-1 and cardiometabolic risk factors in overweight and obese men. J Sports Sci. 2010; 28(9):993-8. https://doi.org/10.1080/02640414.2010.484070 PMID: 20544489.

7. Yang RZ, Lee MJ, Hu H, Pray J, Wu HB, Hansen BC, et al. Identification of omentin as a novel depotspecific adipokine in human adipose tissue: possible role in modulating insulin action. Am J Physiol Endocrinol Metab. 2006; 290(6):E1253-61. https://doi.org/10.1152/ajpendo.00572.2004 PMID: 16531507.

8. Hossein-Nezhad A, Mirzaei K, Alatab S, Ahmadivand Z, Najmafshar A, Peppa M, et al. Circulating omentin-1 in obesity and metabolic syndrome status compared to control subjects. Endocrinol Metabol Syndr. 2012;1:8. https://doi.org/10.4172/2161-1017.S1-008.

9. Verheggen RJ, Poelkens F, Roerink SH, Ramakers RE, Catoire M, Hermus AR, et al. Exercise Improves Insulin Sensitivity in the Absence of Changes in Cytokines. Med Sci Sports Exerc. 2016; 48(12):2378-2386. https://doi.org/10.1249/MSS.0000000000001035 PMID: 27414688.

10. Ansari MH, Gholamnejad M, Meghrazi K, Khalkhali HR. Association of circulating omentin-1 level with lung cancer in smokers. Med J Islam Repub Iran. 2018; 29; 32:133. https://doi.org/10.14196/mjiri.32.133 PMID: 30815428.

11. Jaikanth C, Gurumurthy P, Cherian KM, Indhumathi T. Emergence of omentin as a pleiotropic adipocytokine. Exp Clin Endocrinol Diabetes. 2013; 121(7):377 - 83. https://doi.org/10.1055/s-00331345123 PMID: 23839538.

12. Lazarevic G, Antic S, Cvetkovic T, Djordjevic V, Vlahovic P, Stefanovic V. Effects of regular exercise on cardiovascular risk factors profile and oxidative stress in obese type 2 diabetic patients in regard to SCORE risk. Acta Cardiol. 2008; 63(4):485 - 91. https://doi.org/10.2143/AC.63.4.2033048 PMID: 18795587.

13. Faramarzi M, Banitalebi E, Nori S, Farzin S, Taghavian Z. Effects of rhythmic aerobic exercise plus core stability training on serum omentin, chemerin and vaspin levels and insulin resistance of overweight women. J Sports Med Phys Fitness. 2016; 56(4):476 - 82 PMID: 25651894.

14. Eizadi M, Sohaily S, Khorshidi D, Samarikhalaj H. Effect of Aerobic Training Program on Serum Creactive Protein Levels. Avicenna J Med Biochem. 2016;4(1):e33294. https://doi.org/10.17795/ajmb33294.

15. Matthews DR, Hosker JP, Rudenski AS, Naylor BA, Treacher DF, Turner RC. Homeostasis model assessment: insulin resistance and $\beta$-cell function from fasting plasma glucose and insulin concentrations in man. Diabetologia. 1985; 28(7):412-9. https://doi.org/10.1007/BF00280883 PMID: 3899825. 
16. Chang LC, Huang KC, Wu YW, Kao HL, Chen CL, Lai LP, et al. The clinical implications of blood adiponectin in cardiometabolic disorders. J Formos Med Assoc. 2009;108(5):353-66. https://doi.org/10.1016/S0929-6646(09)60079-6 PMID: 19443289.

17. Davidson LE, Hudson R, Kilpatrick K, Kuk JL, McMillan K, Janiszewski PM, et al. Effects of exercise modality on insulin resistance and functional limitation in older adults: a randomized controlled trial. Arch Intern Med. 2009; 169(2):122 - 31. https://doi.org/10.1001/archinternmed.2008.558 PMID: 19171808.

18. Cai RC, Wei L, Di JZ, Yu HY, Bao YQ, Jia WP. Expression of omentin in adipose tissues in obese and type 2 diabetic patients. Zhonghua Yi Xue Za Zhi. 2009; 89(6):381-4. https://doi.org/10.3760/cma.j.issn.0376-2491.2009.06.009 PMID: 19567114.

19. De Souza Batista CM, Yang RZ, Lee MJ, Glynn NM, Yu DZ, Pray J, et al. Omentin plasma levels and gene expression are decreased in obesity. Diabetes. 2007; 56(6):1655-61. https://doi.org/10.2337/db06-1506 PMID: 17329619.

20. Pan HY, Guo L, Li Q. Changes of serum omentin-1 levels in normal subjects and in patients with impaired glucose regulation and with newly diagnosed and untreated type 2 diabetes. Diabetes Res Clin Pract. 2010; 88(1):29-33. https://doi.org/10.1016/j.diabres.2010.01.013 PMID: 20129687.

21. Lesná J, Tichá A, Hyšpler R, Musil F, Bláha V, Sobotka L, et al. Omentin-1 plasma levels and cholesterol metabolism in obese patients with diabetes mellitus type 1: impact of weight reduction. Nutr Diabetes. 2015; 5(11):e183. https://doi.org/10.1038/nutd.2015.33 PMID: 26524638.

22. Wilms B, Ernst B, Gerig R, Schultes B. Plasma omentin-1 levels are related to exercise performance in obese women and increase upon aerobic endurance training. Exp Clin Endocrinol Diabetes. 2015; 123(3):187 - 92. https://doi.org/10.1055/s-0034-1398504 PMID: 25789872.

23. Ouerghi N, Fradj MK, Bezrati I, Feki M, Kaabachi N, Bouassida A. Effect of high-intensity interval training on plasma omentin-1 concentration in overweight/obese and normal-weight youth. Obes Facts. 2017; 10(4):323-331. https://doi.org/10.1159/000471882 PMID: 28787708.

24. Escoté X, Gómez-Zorita S, López-Yoldi M, Milton-Laskibar I, Fernández-Quintela A, Martínez JA, et al. Role of omentin, vaspin, cardiotrophin-1, TWEAK and NOV/CCN3 in obesity and diabetes development. Int J Mol Sci. 2017; 18(8):1770. https://doi.org/10.3390/ijms18081770 PMID: 28809783.

25. Watanabe K, Watanabe R, Konii H, Shirai R, Sato K, Matsuyama TA, et al. Counteractive effects of omentin-1 against atherogenesis. Cardiovasc Res. 2016; 110(1):118 - 28. https://doi.org/10.1093/cvr/cvw016 PMID: 26790473.

26. Menzel J, di Giuseppe R, Biemann R, Wittenbecher C, Aleksandrova K, Pischon T, et al. Omentin-1 and risk of myocardial infarction and stroke: results from the EPIC-Potsdam cohort study. Atherosclerosis. 2016; 251:415 - 21. https://doi.org/10.1016/j.atherosclerosis.2016.06.003 PMID: 27298015.

27. Wittenbecher C, Menzel J, Carstensen-Kirberg M, Biemann R, di Giuseppe R, Fritsche A, et al. Omentin1, adiponectin, and the risk of developing type 2 diabetes. Diabetes care. 2016; 39(6):e79-80. 
https://doi.org/10.2337/dc15-2702 PMID: 27208328.

28. Ouerghi N, Fradj MK, Talbi E, Bezrati I, Feki M, Bouassida A. Association of selected adipokines with metabolic syndrome and cardio-metabolic risk factors in young males. Cytokine. 2020; 133:155170. https://doi.org/10.1016/j.cyto.2020.155170 PMID: 32554156.

29. Tan BK, Adya R, Farhatullah S, Lewandowski KC, O'Hare P, Lehnert H. Omentin-1, a novel adipokine, is decreased in overweight insulin-resistant women with polycystic ovary syndrome: ex vivo and in vivo regulation of omentin-1 by insulin and glucose. Diabetes. 2008; 57(4):801-8. https://doi.org/10.2337/db07-0990 PMID: 18174521.

30. Moreno-Navarrete JM, Catalán V, Ortega F, Gómez-Ambrosi J, Ricart W, Frühbeck G, et al. Circulating omentin concentration increases after weight loss. Nutr Metab (Lond). 2010; 7:27. https://doi.org/10.1186/1743-7075-7-27 PMID: 20380714.

31. Castro CA, Silva KA, Rocha MC, Sene-Fiorese M, Nonaka KO, Malavazi I, et al. Exercise and omentin: their role in the crosstalk between muscle and adipose tissues in type 2 diabetes mellitus rat models. Front Physiol. 2019; 9:1881. https://doi.org/10.3389/fphys.2018.01881 PMID: 30666216.

32. Alizadeh M, Asad MR, Faramarzi M, Afroundeh R. Effect of eight-week high intensity interval training on omentin-1 gene expression and insulin-resistance in diabetic male rats. Annal Appl Sport Sci. 2017;5(2):29-36. https://doi.org/10.18869/acadpub.aassjournal.5.2.29.

33. Elsaid NH, Sadik NA, Ahmed NR, Fayez SE, Mohammed NA. Serum omentin-1 levels in type 2 diabetic obese women in relation to glycemic control, insulin resistance and metabolic parameters. J Clin Transl Endocrinol. 2018; 13:14-19. https://doi.org/10.1016/j.jcte.2018.05.003 PMID: 30023310.

34. Abd-Elbaky AE, Abo-ElMatty DM, Mesbah NM, Ibrahim SM. Omentin and apelin concentrations in relation to obesity, diabetes mellitus type two, and cardiovascular diseases in Egyptian population. Int J Diabetes Dev Ctries. 2015;36(1):52-8. https://doi.org/10.1007/s13410-015-0416-y.

35. Wajchenberg BL. Subcutaneous and visceral adipose tissue: their relation to the metabolic syndrome. Endocr Rev. 2000; 21(6):697-738. https://doi.org/ 10.1210/edrv.21.6.0415 PMID: 11133069.

36. Yan P, Liu D, Long M, Ren Y, Pang J, Li R. Changes of serum omentin levels and relationship between omentin and adiponectin concentrations in type 2 diabetes mellitus. Exp Clin Endocrinol Diabetes. 2011; 119(04):257 - 63. https://doi.org/ 10.1055/s-0030-1269912 PMID: 21374544.

37. Ferguson MA, Alderson NL, Trost SG, Essig DA, Burke JR, Durstine JL. Effects of four different single exercise sessions on lipids, lipoproteins, and lipoprotein lipase. J Appl Physiol (1985). 1998; 85(3):1169-74. https://doi.org/ 10.1152/jappl.1998.85.3.1169 PMID: 9729596.

\section{Figures}




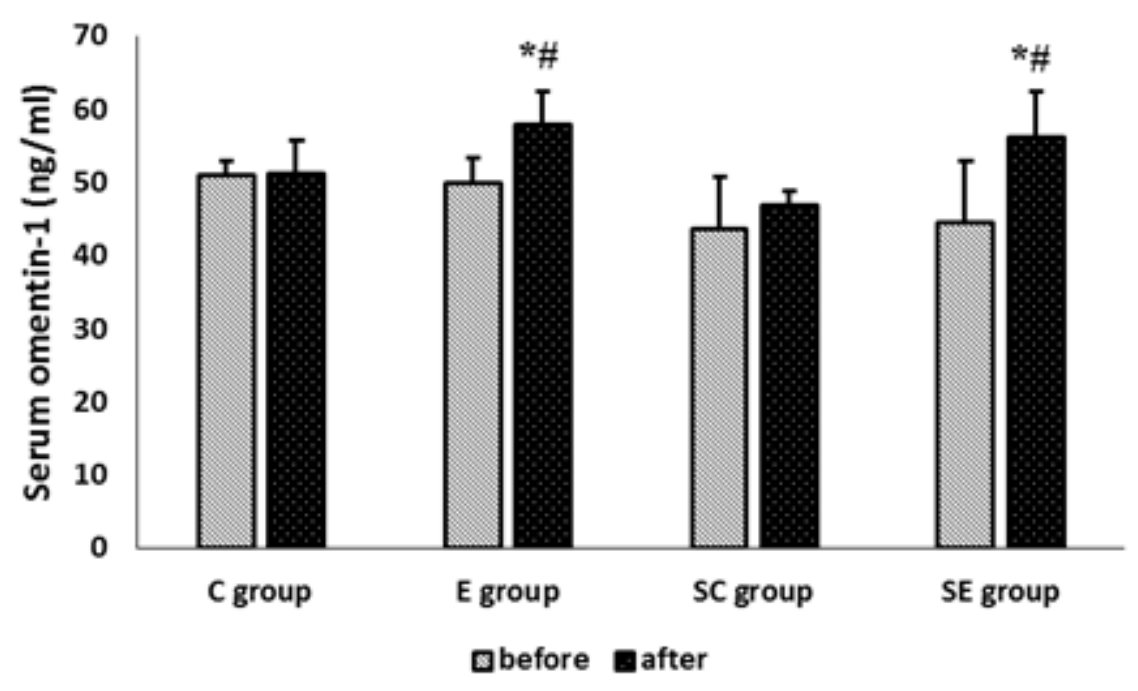

Figure 1

Serum omentin- 1 concentration in all participants before and after eight weeks of aerobic training. ${ }^{*} \mathrm{p}<0.05$; significant difference between pre- and post-exercise training, and $\# p<0.05$; significant difference between exercise group and control group 